\title{
POJAM I VRSTE BAZNOG RIZIKA NA TRŽIŠTU VREMENSKIH IZVEDENICA
}

Vremenske izvedenice iako prisutne na tržištu već više od 20 godina, $i$ dalje predstavljaju nedovoljno istraženo područje u znanstvenoj literaturi, posebice domaćoj. Kao instrumenti zaštite od vremenskog rizika koriste se s ciljem smanjenja volatilnosti odnosno neizvjesnosti budućih novčanih tokova. Uz mnoge prednosti pred alternativnim načinima zaštite od vremenskog rizika, vremenske izvedenice karakterizira značajan bazni rizik koji dokazano smanjuje njihovu učinkovitost $i$ tako ograničava njihovu širu primjenu. Bazni rizik na tržištu vremenskih izvedenica specifičan je i kompleksan. Kako se ne suočavaju svi korisnici vremenskih izvedenica s istom vrstom baznog rizika potrebno je detaljno razumijevanje ovog problema kako bi se kreiralo adekvatno rješenje za upravljanje vremenskim i baznim rizikom. Svrha rada jest detaljno objasniti pojam i vrste baznog rizika na tržištu vremenskih izvedenica, kako i zašto do njega dolazi, njegov utjecaj na učinkovitost vremenskih izvedenica i kako ga minimizirati. Pri tome su korištene sljedeće znanstvene metode: metoda analize, klasifikacije i deskripcije, kombinirana metoda slaganja i razlika, metoda popratnih (zajedničkih) promjena, komparativna metoda, te metode konkretizacije, sinteze i generalizacije. Vrijednost rada ogleda se u sveobuhvatnom pregledu vrsta baznih rizika kojima su korisnici vremenskih izvedenica izloženi i mogućim načinima upravljanja pojedinim vrstama baznih rizika. Znanstveni doprinos rada sastoji se u jedinstvenom zaključku glede utjecaja baznog rizika na učinkovitost vremenskih

${ }^{*}$ Dr. sc. I. Štulec, docentica, Sveučilište u Zagrebu, Ekonomski fakultet (e-mail: istulec@efzg.hr). Rad je primljen u uredništvo 29.03.2018. godine, a prihvaćen je za objavu 30.05.2018. godine. 
izvedenica u zaštiti od vremenskog rizika, neovisno o djelatnosti u kojoj se primjenjuju, donesenom temeljem pregleda brojnih istraživačkih radova.

Ključne riječi: vremenski rizik, vremenske izvedenice, bazni rizik, učinkovitost hedginga.

\section{Uvod}

Neupitan je utjecaj vremenskih prilika na gotovo sve gospodarske sektore i poslovne djelatnosti. Auer (2003) navodi kako je gotovo 80\% svjetskog gospodarstva, izravno ili neizravno, izloženo utjecaju vremenskih prilika. Izloženost vremenskim prilikama definira se kao podložnost prodaje, proizvodnje ili troškova utjecaju meteoroloških elemenata poput temperature, kiše, snijega, sunčeve svjetlosti, vjetra itd. Ukoliko je volatilnost proizvodnje određenog gospodarskog sektora izazvana promjenom u vremenskim prilikama, sektor je neupitno izložen utjecaju vremenskih prilika. Rezultati studije Lazo et al. (2011) pokazuju da su svi gospodarski sektori u određenoj mjeri podložni utjecaju vremenskih prilika, te da podložnost utjecaju varira od sektora do sektora, kao i među geografskim područjima.

Sa sve većim klimatskim promjenama do izražaja dolaze tzv. nekatastrofalne vremenske prilike koje se odnose na manja odstupanja od „normalnih“ odnosno uobičajenih vremenskih prilika kao što su toplija no uobičajena zima i hladnije no uobičajeno ljeto. Osim temperaturnih odstupanja, nekatastrofalne vremenske prilike obuhvaćaju i odstupanja od uobičajene količine kiše i snijega, brzine vjetra, broja sunčanih sati, dana u kojima je zabilježena pojava mraza ili magle itd. Nekatastrofalne vremenske prilike mogu se sažeti na one vremenske uvjete koji utječu na visinu prihoda i/ili troškova poslovnih subjekata no ne ugrožavaju živote i imovinu.

Tijekom godina poduzeća su razvila niz metoda zaštite od nekatastrofalnih vremenskih prilika, međutim svaka od njih ima određene nedostatke što je u konačnici dovelo do razvoja superiornijeg rješenja - vremenskih izvedenica. Vremenske izvedenice su izvedeni financijski instrumenti, tj. instrumenti terminskog tržišta, čija se isplata temelji na nastupu određenih vremenskih prilika u budućnosti, a služe kao sredstvo zaštite od nepovoljnih vremenskih prilika. Ono što je inovativno kod vremenskih izvedenica, i što ih izdvaja u odnosu na klasično osiguranje, jest da je isplata po njima bazirana na osnovu vrijednosti vremenskog indeksa čime se eliminira problem moralnog hazarda i minimizira problem nepovoljne selekcije. S druge strane, s obzirom da isplata po vremenskim izvedenicama nije izravno vezana uz nastalu financijsku štetu, javlja se novi problem, tzv. bazni 
rizik koji se definira kao opasnost da isplata po vremenskoj izvedenici ne bude dovoljna za pokriće financijske štete prouzročene vremenskim prilikama (Woodard i Garcia, 2007). Bazni rizik često se u literaturi ističe kao najveći nedostatak vremenskih izvedenica i prepreka njihovoj široj upotrebi. Bazni rizik na tržištu vremenskih izvedenica specifičan je i kompleksan, i s obzirom da se ne suočavaju svi korisnici vremenskih izvedenica s istom vrstom baznog rizika potrebno je detaljno razumijevanje ovog problema kako bi se kreiralo adekvatno rješenje za upravljanje vremenskim i baznim rizikom.

U skladu s definicijom baznog rizika na tržištu vremenskih izvedenica i načelom sveobuhvatnosti prognoze regresijskog modela u kojem se stvarna financijska šteta nastala nepovoljnim vremenskim prilikama regresira na isplatu po vremenskoj izvedenici, može se postaviti sljedeća hipoteza:

\section{H: Postojanje baznog rizika umanjuje učinkovitost vremenskih izvedenica u zaštiti od vremenskog rizika.}

Navedena hipoteza ispitati će se pregledom brojnih istraživačkih radova na temu baznog rizika na tržištu vremenskih izvedenica i učinkovitosti vremenskih izvedenica u zaštiti od vremenskog rizika u različitim djelatnostima. Kao otvoreno istraživačko pitanje na koje nije moguće hipotetizirati odgovor ostaje: $U$ slučaju da bazni rizik umanjuje učinkovitost vremenskih izvedenica, je li to smanjenje toliko drastično da u potpunosti poništava pozitivan učinak primjene vremenskih izvedenica u zaštiti od vremenskog rizika?

Svrha ovog rada jest sveobuhvatno objasniti pojam baznog rizika na tržištu vremenskih izvedenica, kako i zašto do njega dolazi, te raspraviti utjecaj baznog rizika na učinkovitost vremenskih izvedenica i predložiti moguće načine minimizacije baznog rizika. Pregledom literature utvrđeni su brojni radovi koji konceptualno obrađuju ili empirijski istražuju problem baznog rizika na tržištu vremenskih izvedenica, međutim autori se bave izdvojenim vrstama baznog rizika i ne daju sveobuhvatan pregled svih mogućih uzroka baznog rizika. Vrijednost i doprinos ovog rada ogleda se upravo u sveobuhvatnom pregledu vrsta baznih rizika s kojima se korisnici vremenskih izvedenica mogu susresti i mogućim načinima upravljanja pojedinim baznim rizicima. Temeljem pregleda brojnih istraživanja donesen je jedinstveni zaključak o utjecaju baznog rizika na učinkovitost vremenskih izvedenica u zaštiti od vremenskog rizika, neovisno o djelatnosti u kojoj se primjenjuju, što je ujedno i najveći znanstveni doprinos ovog rada.

Korištene su sljedeće metode znanstvenog rada. Metode kauzalne i komparativne analize korištene su prilikom definiranja i određivanja prirode vremenskog rizika u različitim djelatnostima. Pri definiranju mogućih vrsta baznih rizika na tržištu vremenskih izvedenica korištene su metode klasifikacije i metode deskrip- 
cije. U istraživanju i uspoređivanju težine pojedinih vrsta baznih rizika u ukupnom baznom riziku kojemu se korisnik vremenske izvedenice izlaže korištena je kombinirana metoda slaganja i razlike, metoda popratnih (zajedničkih) promjena, te komparativna metoda. U izvođenju zaključaka korištene su metode konkretizacije, sinteze i generalizacije.

Rad je strukturiran kako slijedi. Nakon uvodnog dijela definiraju se pojmovi vremenskog rizika i vremenskih izvedenica. U trećem dijelu najprije se općenito objašnjava bazni rizik, a zatim specifičnosti baznog rizika na tržištu vremenskih izvedenica. Četvrti dio ujedno je i najopsežniji dio rada i donosi iscrpni teorijski pregled vrsta baznog rizika na tržištu vremenskih izvedenica, te pregled istraživanja o utjecaju baznog rizika na učinkovitost vremenskih izvedenica u različitim djelatnostima. Peti dio donosi diskusiju rezultata i novih spoznaja. Zaključni dio sažima najvažnije teorijske spoznaje rada.

\section{Vremenski rizik i vremenske izvedenice}

Najcitiranija definicija vremenskog rizika jest definicija Brocketta, Wanga i Yanga (2005) i Wanga, Wena i Yanga (2010) koji vremenski rizik definiraju kao nesigurnost u budućim novčanim tokovima koja se javlja kao posljedica nekatastrofalnih vremenskih prilika. Iz dane definicije moguće je zaključiti, iako to autori izrijekom ne navode, da se pod terminom vremenski rizik podrazumijeva sveukupan (povoljan i nepovoljan) utjecaj vremenskih prilika. U skladu s općenitom definicijom upravljanja rizicima Schmita i Rotha (1990) i Banksa (2004), upravljanje vremenskim rizikom može se definirati kao poduzimanje aktivnosti s ciljem minimiziranja negativnih učinaka i maksimiziranja pozitivnih učinaka vremenskih prilika na poslovanje poduzeća. Kao i kod upravljanja rizicima općenito, tako i kod upravljanja vremenskim rizikom, svrha jest smanjiti odstupanje od očekivanih novčanih tokova poduzeća i na taj način osigurati prihvatljive stope po kojima se posuđuje vanjski kapital (Stulz, 1996), smanjiti ovisnost o vanjskom kapitalu (Bartram, 2000), te u konačnici povećati tržišnu vrijednost poduzeća i bogatstvo dioničara (Mseddi i Abid, 2010).

Vremenski rizik je sveprisutan, no u jeku gospodarske krize poslovni subjekti često su primorani najprije osigurati opstanak poslovanja, a tek onda stabilnost novčanih tokova. Promatrano relativno, izloženost hrvatskog gospodarstva vremenskom riziku procjenjuje se na 34\% BDP-a, a kao najosjetljiviji sektor na vremenske prilike izdvaja se prerađivački sektor (Weatherbill, 2008). Rezultati iste studije pokazuju kako bi zaštita od vremenskog rizika rezultirala većim gospodarskim rastom u Republici Hrvatskoj od 162 milijuna dolara odnosno 0,542\% 
BDP-a. Štoviše, kada bi se zaštiti od vremenskog rizika pristupilo globalno, sveobuhvatna strategija zaštite rezultirala bi većim rastom BDP-a u svijetu za 258 milijardi dolara godišnje.

Vremenske izvedenice kreirane su sa svrhom zaštite od nekatastrofalnih vremenskih prilika, dok se za zaštitu od katastrofalnih posljedica vremenskih neprilika tradicionalno koristi osiguranje. Vremenske izvedenice instrument su terminskog tržišta i hrvatsko ih pravo definira kao ,izvedene financijske instrumente koji se odnose na klimatske varijable“, te kao takve podliježu Zakonu o tržištu kapitala (NN 88/08). U podlozi vremenskih izvedenica stoji vremenski indeks dobiven na temelju opažanja stvarnih meteoroloških elemenata (vremenskih prilika) u referentnoj meteorološkoj stanici tijekom određenog vremenskog perioda, a isplata po vremenskim izvedenicama ovisi o odstupanju kumulativne vrijednosti izabranog vremenskog indeksa od prethodno definirane izvršne razine koja se najčešće određuje kao prosječna vrijednost vremenskog indeksa tijekom izabranog broja godina. Svakom stupnju odstupanja pridana je određena novčana vrijednost i na taj način je vrijeme pretvoreno u dobro kojim je moguće trgovati, tj. u robu (prilagođeno prema Lazibat, Županić i Baković (2009)). Primjenom vremenskih izvedenica poduzeća se štite tako da na terminskom tržištu sklope transakciju koja im donosi dobit u slučaju nastupa vremenskih prilika koje imaju nepovoljan utjecaj na njihovo poslovanje. Na taj način ostvaruje se zaštita od nepovoljnih vremenskih prilika primjenom instrumenata terminskog tržišta, odnosno tzv. weather hedge (engl). Potencijalna primjena vremenskih izvedenica u prodaji osvježavajućih pića u trgovini na malo funkcionirala bi na način da se maloprodavač osvježavajućih pića štiti od hladnijeg no uobičajenog ljeta tako da na terminskom tržištu sklopi transakciju koja će mu osigurati isplatu u slučaju nižih no uobičajenih temperatura. Na taj cee način gubitak u prodaji nadoknaditi dobitkom na terminskom tržištu.

Vremenskim izvedenicama, kao i ostalim financijskim izvedenicama, može se trgovati organizirano putem institucionalnog (burzovnog) tržišta ili dogovorno putem tržišta preko šaltera specijaliziranih trgovaca (engl. over the counter - OTC) (Lazibat, Štulec i Baković, 2011). Tvrtke se odlučuju na zaštitu od nepovoljnih vremenskih prilika upotrebom vremenskih izvedenica najčešće kako bi smanjile volatilnost ostvarenih profita, pokrile prekomjerne troškove, nadoknadile izgubljene prihode, stimulirale prodaju i diversificirale investicijski portfelj (Leggio, 2007).

Primarna svrha primjene vremenskih izvedenica, kao i preostalih instrumenata zaštite od vremenskog rizika, jest smanjenje volatilnosti ostvarenih prihoda i/ili troškova izazvane promjenjivošću nekatastrofalnih vremenskih prilika. Vremenske izvedenice kao učinkovito sredstvo upravljanja vremenskim rizikom smanjuju volatilnost profita poduzeća te im tako povećavaju kreditni rejting i osi- 
guravaju niže stope po kojima posuđuju kapital. U skladu s time, učinkovitost vremenskih izvedenica može se definirati kao sposobnost vremenskih izvedenica u smanjivanju volatilnosti ostvarenih profita, odnosno prihoda i/ili troškova.

Učinkovitost vremenskih izvedenica dokazana je u energetici (Leggio i Lien, 2002; Pres, 2009), vinogradarstvu (Zara, 2010), ratarstvu (Spaulding et al., 2003; Vedenov i Barnett, 2004; Cafiero et al., 2007; Woodard i Garcia, 2007; Torriani et al., 2008; Marković i Jovanović, 2011; Vedenov i Sanchez, 2011; Ender i Zhang, 2015), mljekarstvu (Chen i Roberts, 2004; Chen, Roberts i Thraen, 2006; Deng et al. 2007), turizmu (Leggio, 2007; Tang i Jang, 2010) i maloprodaji osvježavajućih pića (Štulec, 2017). Spomenuti autori ocjenu o učinkovitosti vremenskih izvedenica donijeli su na osnovu usporedbe novčanih tokova sa i bez primjene vremenskih izvedenica, odnosno temeljem usporedbe novčanih tokova sa i bez isplate po vremenskim izvedenicama.

\section{Bazni rizik}

U općenitoj terminologiji terminske trgovine, baza se definira kao razlika između promptne i terminske cijene odnosnog financijskog instrumenta (Ederington, 1979). Promatra li se tržište robnih izvedenica, baza predstavlja razliku između promptne cijene realne robe i terminske cijene robnog terminskog ugovora. $\mathrm{U}$ vremenu $t$ baza se može prikazati formulom (Alexander, 2008):

$$
B(t, T)=C P(t)-F P(t, T) .
$$

$B$ označava bazu, $C P$ promptnu cijenu (engl. cash price), $F P$ terminsku cijenu (engl. futures price), $t$ sadašnje vrijeme i $T$ dospijeće terminskog ugovora. Rezultat hedginga kao strategije zaštite od nepovoljnog kretanja cijene financijskih i robnih izvedenica ovisiti će o promjeni baze. Hedge se smatra savršenim ako baza ostane nepromijenjena (Ederington, 1979), odnosna ako razlika između promptne i terminske cijene u promatranom vremenu $T$ - $t$ bude konstantna, jer će u tom slučaju dobici na terminskome tržištu u potpunosti nadoknaditi gubitke na promptnom tržištu. Sukladno tome, bazni rizik se može definirati kao opasnost da promptne i terminske cijene neće jednako fluktuirati tijekom promatranog vremenskog perioda i reflektira nesigurnost glede budućih vrijednosti baze.

Manfredo i Richards (2009) regresirali su promptne cijene na terminske cijene i preostalo rezidualno odstupanje definirali kao bazni rizik;

$$
C P_{t}=\alpha+\beta F P_{t}+e_{t} .
$$


$C P$ označava promptnu cijenu, FP terminsku cijenu, indeks $t$ vrijeme i $e$ rezidualni bazni rizik. Regresijski model sa promptnom cijenom kao zavisnom varijablom i terminskom cijenom kao nezavisnom varijablom često se koristi u usporedbi učinkovitosti dvaju različitih instrumenata terminskih tržišta, primjerice linearnih i nelinearnih strategija trgovanja. Navedena metoda usporedbe naziva se načelo sveobuhvatnosti prognoze (engl. forecast encompassing principle), a usporedba se vrši na osnovu koeficijenta determinacije regresijskog modela (Manfredo i Richards, 2009). Instrument terminskog tržišta s višim koeficijentom determinacije smatra se učinkovitijim u zaštiti od cjenovnog rizika zato što objašnjava veći postotak varijabilnosti (fluktuacije) cijene promatrane robe, odnosno prognoza kretanja promptne cijene robe je obuhvatnija.

Bazni rizik vremenskih izvedenica nešto je teže objasniti primjenom načela sveobuhvatnosti prognoze zato što vremenske prilike nisu fizičko dobro i ne postoji promptno (fizičko) tržište vremenskih prilika. Drugim riječima, postavlja se pitanje što koristiti kao zavisnu varijablu u regresijskom modelu načela sveobuhvatnosti prognoze. Manfredo i Richards (2009) uspoređivali su bazni rizik dviju alternativnih vremenskih izvedenica (vremenskog terminskog ugovora i opcije na vremenski terminski ugovor) i problem nepostojanja fizičkog tržišta za vremenske prilike riješili su tako što su regresirali stvarno nastalu financijsku štetu uzrokovanu vremenskim prilikama na isplatu po vremenskim izvedenicama. Bazni rizik je, kao i u slučaju klasičnih izvedenica, mjeren kao rezidualno odstupanje tako postavljenog regresijskog modela. U skladu s time, bazni rizik na tržištu vremenskih izvedenica se može definirati kao rizik, odnosno kao opasnost, da isplata po vremenskoj izvedenici neće biti dovoljna za pokriće financijske štete prouzročene vremenskim prilikama (Woodard i Garcia, 2007), a mjeri se kao razlika između stvarne financijske štete i isplate po vremenskoj izvedenici (Rohrer, 2004). Spaulding et al. (2003) dodaju kako bazni rizik na tržištu vremenskih izvedenica također podrazumijeva mogućnost da isplata po vremenskoj izvedenici bude veća od štete prouzročene vremenskim prilikama.

Do odstupanja isplate po vremenskoj izvedenici od štete prouzročene vremenskim prilikama dolazi zbog toga što se isplata zasniva na vrijednosti vremenskog indeksa, a ne na stvarno nastaloj financijskoj šteti (Jewson i Brix, 2005). Drugim riječima, do odstupanja isplate od stvarno nastale štete dolazi zato što su vremenske izvedenice instrument zaštite od uzroka rizika (nepovoljnih vremenskih prilika), a ne posljedica nastale štete (smanjene prodaje ili proizvodnje, većih troškova itd.) kao što je primjerice klasično osiguranje.

Moser i Helms (1990) navode da ulazeći u strategiju hedginga, investitori zapravo zamjenjuju cjenovni rizik za bazni rizik. Bazni rizik kojem je poslovni subjekt izložen prilikom primjene određene strategije zaštite (hedginga) može imati značajan utjecaj na učinkovitost instrumenata terminskog tržišta u smanjivanju cjenovnog rizika (Ederington, 1979). Alexander (2008) navodi da mogućnost trgo- 
vanja na promptnom tržištu smanjuje bazni rizik, stoga instrumenti za koje uopće ne postoji promptno tržište kao što su vremenske izvedenice, uobičajeno imaju veći bazni rizik. Sukladno tome, bazni rizik se često navodi kao glavna prepreka široj primjeni vremenskih izvedenica (Turvey, 2005; Brockett, Wang i Yang, 2005, Deng et al., 2007; Lin et al., 2015; Url, Sinabell, i Heinschink, 2018).

\section{Vrste baznog rizika na tržištu vremenskih izvedenica}

Statistički gledano, bazni rizik proizlazi iz nesavršenosti korelacije isplate po vremenskoj izvedenici i štete prouzročene vremenskih prilikama, a sama nesavršenost korelacije rezultat je većeg broja činitelja. Nesavršenost korelacije između isplate po vremenskoj izvedenici i nastale štete može biti rezultat (1) nesavršenosti korelacije između vremenskog indeksa u podlozi vremenske izvedenice i zavisnih rezultata poslovanja (Liu, 2006), te nepodudaranja (2) vremenskog perioda i (3) lokacije meteorološke stanice na koju glasi vremenska izvedenica sa izloženošću stvarne lokacije koju se želi zaštititi (Golden, Wang i Yang, 2007). Može se zaključiti da na ukupni bazni rizik utječe više čimbenika, i u skladu s time, moguće je definirati više vrsta baznog rizika. Chen i Roberts (2004) spominju geografski i indeksni bazni rizik, Rohrer (2004) geografski, temporalni i proizvodni, Deng et al. (2007) geografski i temporalni bazni rizik, te Woodard i Garcia (2007) lokalni, geografski i proizvodni bazni rizik. Na osnovu toga izvršena je klasifikacija na ukupno pet vrsta baznog rizika s kojima se susreću korisnici vremenskih izvedenica; geografski, temporalni, proizvodni, indeksni i lokalni bazni rizik. Također, mnogi autori (Considine, 2000; Gardner, 2003; Brockett, Wang i Yang, 2005; Jones, 2007) u svojim radovima spominju općenito termin bazni rizik bez da pobliže odrede vrstu baznog rizika. Međutim, iz objašnjenja pojma se može zaključiti da autori misle na geografski bazni rizik iako to izrijekom ne navode, što ne čudi s obzirom da je geografski bazni rizik najzastupljenija vrsta baznog rizika u znanstvenoj literaturi iz područja vremenskih izvedenica i zaštite od vremenskog rizika. Razumijevanje baznog rizika, te njegovih uzroka i posljedica, od iznimne je važnosti za učinkovito upravljanje vremenskim rizikom stoga su u nastavku pobliže objašnjene vrste baznog rizika.

\subsection{Geografski bazni rizik}

Osim što je najzastupljenija vrsta baznog rizika u literaturi općenito, geografski bazni rizik (engl. geographic, spatial, location basis risk) također je najzastu- 
pljenija vrsta baznog rizika u empirijskim istraživanjima (van Asseldonk, 2003; Chen i Roberts, 2004; Deng et al., 2007; Golden, Wang i Yang, 2007; Woodard i Garcia, 2007; Yang, Brockett i Wen, 2009; Yang, Li i Wen, 2011). Geografski bazni rizik se javlja kada vremenski indeks koji je u podlozi vremenske izvedenice nije mjeren na konkretnoj lokaciji koju se želi zaštititi od vremenskog rizika (lokalnoj meteorološkoj stanici), već na nekoj drugoj lokaciji (ne-lokalnoj meteorološkoj stanici). Problem geografskog baznog rizika najčešće se javlja u dva slučaja: kada se želi zaštititi lokacija koja nije uvrštena među gradove ponuđene na organiziranom terminskom tržištu kao što je Chicago Mercantile Exchange (CME) i kada se želi zaštititi široko geografsko područje za koje ne postoji jedinstvena reprezentativna vremenska postaja.

Kao najveći nedostatak organiziranog tržišta vremenskih izvedenica spominje se upravo geografski bazni rizik (Considine, 2000). Naime, organizirano tržište vremenskih izvedenica nudi standardizirane vremenske izvedenice što znači da su, uza sve ostale elemente ugovora, unaprijed zadani gradovi u kojima se mogu vršiti meteorološka mjerenja. Kako su vremenske prilike visoko lokalizirane, trgovac koji želi kupiti zaštitu od nepovoljnih vremenskih prilika za grad koji nije uvršten u ponudu na organiziranom terminskom tržištu suočava se s geografskim baznim rizikom. Primjerice, burza CME trenutno nudi vremenske izvedenice na svega osam gradova u SAD-u i dva u Europi (CME, 2018). S druge strane, na OTC tržištu ugovori se kreiraju prema konkretnim potrebama sudionika, stoga je moguće kreirati ugovor koji glasi gotovo na svaku geografsku lokaciju. Yang, Li i Wen (2011) proveli su empirijsko istraživanje geografskog baznog rizika tako što su stavili u omjer učinkovitost standardiziranih vremenskih izvedenica (kojima se trguje na CME) i nestandardiziranih vremenskih izvedenica (kojima se trguje na OTC tržištu). Standardizirani ugovori pisani su na ne-lokalne meteorološke stanice stoga uključuju geografski bazni rizik, dok su nestandardizirane vremenske izvedenice pisane na lokalnu meteorološku stanicu i ne uključuju geografski bazni rizik. Studija je provedena na europskim gradovima, a rezultati pokazuju da postojanje geografskog baznog rizika umanjuje učinkovitost zaštite od vremenskog rizika, odnosno da su standardizirane vremenske izvedenice manje učinkovite od nestandardiziranih vremenskih izvedenica. Također je utvrđeno da bazni rizik varira po mjesecima, te da se nelinearne strategije zaštite (put opcije) ne mogu bezrezervno smatrati superiornijom zaštitom u odnosu na linearne strategije zaštite (terminske ugovore).

Drugi slučaj u kojem se javlja problem geografskog baznog rizika jest slučaj kada se želi zaštititi široko geografsko područje jer se zavisna varijabla poslovanja (prodaja ili proizvodnja) ostvaruje na geografski razgranatom području. Kao primjeri mogu se navesti poljoprivredna proizvodnja, te distribucija plina i električne energije u regiji ili zemlji. U tim slučajevima postavlja se pitanje na kojoj lokaciji 
vršiti meteorološko mjerenje. Uobičajeno pristupanje problemu jest da se mjerenja vrše u centralnom ili najvećem gradu regije ili države (Leggio i Lien, 2002; Chen i Roberts, 2004; Vedenov i Barnett, 2004; Chen, Roberts i Thraen, 2006; Woodard i Garcia, 2007; Blom, 2009; Manfredo i Richards, 2009; Zara, 2010) ili da se mjerenja vrše u većem broju meteoroloških postaja, a finalna vrijednost vremenskog indeksa u podlozi vremenske izvedenice da se odredi kao ponderirani prosjek navedenih mjerenja (Woodard i Garcia, 2007; Yang, Brockett i Wen, 2009; Ritter, Mußhoff i Odening, 2014). U slučaju ponderirane vrijednosti vremenskog indeksa, ponderi se najčešće određuju u skladu s brojem potrošača, te udjelom prodaje ili proizvodnje pojedinih lokacija. Yang, Brockett i Wen (2009) ispitivali su utjecaj geografskog baznog rizika na učinkovitost vremenskih izvedenica tako što su uspoređivali učinkovitost (standardiziranih) vremenskih izvedenica pisanih na vremenski indeks mjeren u jednoj meteorološkoj postaji i učinkovitost (regionalnih, OTC) vremenskih izvedenica pisanih na vremenski indeks dobiven kao prosjek mjerenja u deset meteoroloških postaja u regiji. Suprotno očekivanjima, rezultati pokazuju da vremenske izvedenice pisane na regionalne indekse nisu konzistentno superiornije u odnosu na vremenske izvedenice pisane na vremenske indekse mjerene u jednoj meteorološkoj stanici. Za razliku od toga, rezultati studije Woodarda i Garcie (2007) pokazuju da su vremenske izvedenice pisane na vremenski indeks dobiven kao ponderirani prosjek mjerenja sa većeg broja meteoroloških postaja učinkovitije u zaštiti od vremenskog rizika u usporedbi s vremenskim izvedenicama pisanima na vremenske indekse mjerene u pojedinačnim ne-lokalnim meteorološkim postajama.

U svakom slučaju, kada vremensku izvedenicu nije moguće pisati na vremenski indeks mjeren u lokalnoj meteorološkoj postaji (koja podrazumijeva ne postojanje geografskog baznog rizika), postavlja se pitanje u kojoj ne-lokalnoj meteorološkoj postaji mjeriti vremenski indeks. I po ovom pitanju, rezultati empirijskih istraživanja su podijeljeni. Deng et al. (2007) utvrdili su da što je veća udaljenost ne-lokalne meteorološke postaje od lokalne meteorološke postaje, to je veći i geografski bazni rizik, odnosno manja učinkovitost vremenskih izvedenica kao instrumenata zaštite od vremenskog rizika. S druge strane, Chen i Roberts (2004) su dokazali da ne postoji jasna povezanost između udaljenosti meteoroloških postaja i smanjenja učinkovitosti vremenskih izvedenica. Može se zaključiti da u slučaju nemogućnosti mjerenja vremenskog indeksa u lokalnoj meteorološkoj postaji, ne postoji jedinstveni zaključak u kojoj ne-lokalnoj meteorološkoj postaji vršiti mjerenje, te da najbolja alternativa nije uvijek najbliža ne-lokalna meteorološka postaja već ona koja pokazuje visok stupanj povezanosti sa relevantnim meteorološkim elementima u lokalnoj meteorološkoj postaji.

Alternativni način smanjivanja geografskog baznog rizika jest kreiranje novog terminskog ugovora, tzv. bazne izvedenice (engl. basis derivatives). Primjerice, 
temelji li se vremenska izvedenica na temperaturnom indeksu, geografski bazni rizik predstavljat će razliku u stupnjevima topline između lokacije uvrštene na organizirano tržište (ne-lokalne meteorološke postaje) i stvarne lokacije koja je izložena vremenskome riziku (lokalne meteorološke postaje). U tom slučaju, u podlozi bazne izvedenice stajati će razlika u stupnjevima topline između dotične dvije lokacije (Golden, Wang, Yang, 2007). Međutim, bazne izvedenice također su instrumenti OTC tržišta tako da nose značajan kreditni rizik (Brocket, Wang, Yang, 2005).

Primjena nestandardizirane bazne izvedenice u kombinaciji sa standardiziranom vremenskom izvedenicom naziva se bazni hedging (engl. basis hedging). Bazni hedging se koristi kada standardizirani vremenski terminski ugovori ne pokrivaju dotičnu geografsku lokaciju koju hedger želi zaštititi od vremenskog rizika (zbog čega je hedger primoran transakciju sklopiti na OTC tržištu) i kada hedger želi minimizirati kreditni rizik (zbog čega preferira sklapanje transakcije na organiziranom terminskom tržištu). Bazni hedging predstavlja kompromisno rješenje koje omogućuje minimizaciju kreditnog rizika i geografskog baznog rizika. Ostvaruje se sklapanjem standardizirane vremenske izvedenice na ne-lokalnu meteorološku postaju na organiziranom terminskom tržištu (što podrazumijeva geografski bazni rizik, ali eliminira kreditni rizik) i tzv. bazne izvedenice odnosno nestandardizirane vremenske izvedenice u čijoj podlozi stoji razlika između vrijednosti vremenskog indeksa izmjerenog u ne-lokalnoj i lokalnoj meteorološkoj postaji (Golden, Wang i Yang, 2007). Bazni hedging može se provesti i pomoću linearnih strategija trgovanja (npr. vremenskih terminskih ugovora) i pomoću nelinearnih strategija trgovanja (npr. vremenskih opcija).

Golden, Wang i Yang (2007) su ispitivali kako vremenski, bazni i kreditni rizik utječu na učinkovitost vremenskih izvedenica u zaštiti od nepovoljnog utjecaja temperature na potrošnju električne energije u slučaju baznog hedginga. Vremenski rizik mjerili su kao standardnu devijaciju vremenskog indeksa, bazni rizik kao korelaciju između vremenskog indeksa izmjerenog u lokalnoj i ne-lokalnoj meteorološkoj postaji, te kreditni rizik kao vjerojatnost da suprotna strana u transakciji neće ispuniti preuzete obveze. Kao mjeru učinkovitosti autori su koristili minimizaciju varijance. Rezultati istraživanja pokazuju da učinkovitost baznog hedginga raste što je vremenski rizik veći i što je bazni rizik manji, i konzistentni su za linearne i nelinearne strategije trgovanja. Za razliku od toga, kreditni rizik ima neutralan utjecaj na učinkovitost linearnog baznog hedginga i pozitivan utjecaj na učinkovitost nelinearnog baznog hedginga.

Postoje podijeljena mišljenja da su pojedini meteorološki elementi, kao što je primjerice kiša, u većoj mjeri izloženi geografskom baznom riziku. Turvey (2005) i Vedenov i Barnett (2004) smatraju da geografski bazni rizik posebice dolazi do izražaja kod vremenskih izvedenica kreiranih na osnovu kiše zbog toga što mala udaljenost od referentne mjerne postaje može rezultirati velikim razlikama u koli- 
čini padalina. S druge strane, Dischel (2002) je analizirao korelaciju količine kiše u tri sjevernoamerička grada i na osnovu visokih koeficijenata korelacije zaključio da je geografski bazni rizik koji se veže uz vremenske izvedenice na kišu precijenjen, te da je u stvarnosti mnogo niži.

\subsection{Temporalni bazni rizik}

Sve vremenske izvedenice imaju definirani početak i kraj vremenskog razdoblja kojeg pokrivaju, odnosno tijekom kojeg se mjeri vrijednost vremenskog indeksa u podlozi izvedenice. Temporalni bazni rizik (engl. temporal, time, calender basis risk) javlja se u slučaju nepodudaranja perioda stvarne izloženosti vremenskome riziku i perioda koji je pokriven vremenskom izvedenicom (Rohrer, 2004), primjerice kada je vremenskom izvedenicom pokriven predugi vremenski period. Temporalni bazni rizik javlja se iz dva razloga: (1) zato što distribucija vjerojatnosti vremenskog indeksa nije stacionarna tijekom promatranog perioda i/ili (2) zato što vremenske prilike imaju različiti utjecaj na zavisnu varijablu poslovanja tijekom različitih vremenskih perioda (Deng et al., 2007). Zbog toga je vrlo važno pravilno odabrati vremenski period kojeg vremenska izvedenica pokriva.

Sezonalnost vremenskih prilika uzrokuje nestacionarnost distribucije vjerojatnosti vremenskog indeksa tijekom promatranog perioda u kojem se želi sklopiti zaštita od vremenskog rizika. Nestacionarnost distribucije manifestira se kao praktičan problem tako što prosjek meteorološkog elementa na osnovu kojeg je kreiran vremenski indeks nije jednak tijekom cijelog promatranog perioda i tijekom podperioda na koje se cijeli promatrani period može podijeliti. S obzirom da se izvršna razina vremenskih izvedenica najčešće određuje kao povijesni prosjek vremenskih prilika, nestacionarnost može dovesti do podcjenjivanja ili precjenjivanja izvršne razine što posljedično ima utjecaj na cijenu i učinkovitost vremenskih izvedenica. Drugi razlog koji može uzrokovati temporalni bazni rizik je različiti utjecaj vremenskih prilika na zavisnu varijablu poslovanja u promatranom periodu i pod-periodima na koje se period koji se želi zaštititi od vremenskog rizika može podijeliti. S obzirom da se novčana vrijednost jediničnog pomaka vremenskog indeksa određuje na osnovu veličine utjecaja vremenskih prilika, različitost utjecaja također može dovesti do precjenjivanja ili podcjenjivanja isplate po vremenskim izvedenicama što posljedično također utječe na učinkovitost vremenskih izvedenica.

Deng et al. (2007) ispitivali su utječe li postojanje temporalnog baznog rizika na učinkovitost vremenskih izvedenica u mljekarstvu tako što su ukupni promatrani period podijelili u dva pod-perioda: jedan kojeg karakterizira toplije vrijeme i drugi kojeg karakterizira hladnije vrijeme. Za svaki pod-period kreirali su zaseb- 
nu vremensku izvedenicu sa različitom strukturom i funkcijom isplate, te ispitivali učinkovitost izvedenica koje pokrivaju pojedine pod-periode i cjelokupni promatrani period. Rezultati pokazuju da primjena zasebnih vremenskih izvedenica za svaki pod-period rezultira učinkovitijom zaštitom od vremenskog rizika u usporedbi s jedinstvenom vremenskom izvedenicom za cijelo razdoblje, što dokazuje da temporalni bazni rizik umanjuje učinkovitost vremenskih izvedenica. Yang, Brockett i Wen (2009) su ispitivali učinkovitost vremenskih izvedenica u sektoru energetike, a kao zavisnu varijablu poslovanja promatrali su potrošnju električne energije tijekom godine. Rezultati pokazuju da se učinkovitost vremenskih izvedenica razlikuje u zimskom i ljetnom dijelu godine, te da je učinkovitost veća ljeti nego zimi. Ovakvi rezultati mogu se objasniti time što se električna energija većinom koristi ljeti za pokretanje klimatizacijskih uređaja, dok je u zimskom razdoblju prirodni plin dominantan energent. Nadalje, zimski i ljetni period deagregirani su na individualne mjesece i za svaki mjesec zasebno je kreirana i ispitana učinkovitost vremenskih izvedenica. Rezultati pokazuju da osim što učinkovitost vremenskih izvedenica varira od sezone do sezone, također varira i od mjeseca od mjeseca unutar iste sezone. Ovakvi rezultati u skladu su s rezultatima Presa (2009) i Yanga, Lia i Wena (2011) koji također potvrđuju da učinkovitost vremenskih izvedenica varira od mjeseca do mjeseca.

Rezultati empirijskih istraživanja impliciraju da poslovni subjekti, iako zabrinuti zbog utjecaja vremenskih prilika tijekom određene sezone (ljetne ili zimske), ne trebaju sklopiti jedinstveni terminski ugovor koji će pokriti cijelu sezonu, već mogu izabrati jedan ili više mjesečnih terminskih ugovora koji pokrivaju mjesece u kojima je dokazana visoka učinkovitost vremenskih izvedenica. Tako primjerice, za potrebe poljoprivrede Dalhaus, Musshoff i Finger (2018) predlažu prilagođavanje vremenskog perioda kojeg izvedenica pokriva fenološkim fazama rasta pojedinih kultura s ciljem minimiziranja temporalnog baznog rizika. Naravno, u slučaju sklapanja većeg broja terminskih ugovora, multipliciraju se transakcijski troškovi što nepovoljno utječe na cijenu vremenskih izvedenica. Stoga je prilikom razmatranja perioda kojeg će vremenska izvedenica pokriti i broja terminskih ugovora koje korisnik namjerava sklopiti, potrebno izvršiti kompromis između temporalnog baznog rizika i transakcijskih troškova (Deng et al., 2007).

\subsection{Proizvodni bazni rizik}

Proizvodni bazni rizik (engl. product basis risk) odnosi se na razliku u učinkovitosti alternativnih vremenskih izvedenica u zaštiti od vremenskog rizika (Woodard i Garcia, 2007). Pri tome se alternativnim vremenskim izvedenicama 
smatraju vremenske izvedenice kreirane na osnovu različitih meteoroloških elemenata (temperature, kiše, snijega, vjetra itd). Ova je vrsta baznog rizika izrazito rijetko zastupljena u empirijskim istraživanjima, uglavnom zbog toga što poslovni subjekti znaju koji im meteorološki element predstavlja najveću prijetnju u poslovanju. Izuzetak je, primjerice, poljoprivredna djelatnost gdje na količinu i kvalitetu usjeva utječe više od jednog meteorološkog elementa, najčešće kiša i temperatura, i potrebno je provesti kvantitativnu analizu kako bi se utvrdilo koji meteorološki element ima jači utjecaj, odnosno na osnovu kojeg meteorološkog elementa treba kreirati vremensku izvedenicu kako bi se postigla što učinkovitija zaštita od vremenskog rizika.

Postoje studije u kojima je razmatrana primjena vremenskih izvedenica na osnovu temperature (Leggio i Lien, 2002; van Asseldonk, 2003; Turvey, 2005; Manfredo i Richards, 2009; Yang, Brockett i Wen, 2009; Yang, Li i Wen, 2011) i na osnovu kiše (Sinha i Baqueiro, 2005; Turvey, 2005; Leggio, 2007; Marković i Jovanović, 2011), no samo su Woodard i Garcia (2007) proveli usporedbu učinkovitosti dviju alternativnih vremenskih izvedenica. Autori su uspoređivali učinkovitost call opcije na temperaturu i put opcije na kišu u zaštiti od nepovoljnog utjecaja temperature, odnosno kiše, na usjeve kukuruza. Rezultati studije pokazuju da su temperaturne izvedenice učinkovitije od izvedenica na kišu u zaštiti od vremenskog rizika u proizvodnji kukuruza. Međutim, s obzirom da ne postoje druge studije o usporedbi alternativnih vremenskih izvedenica, ne može se općenito tvrditi da su izvedenice na kišu manje učinkovite od izvedenica na temperaturu jer značajnost $\mathrm{i}$ utjecaj pojedinih meteoroloških elemenata na zavisnu varijablu poslovanja ovisi o djelatnosti koju se promatra. Nadalje, Woodard i Garcia (2007) su usporedili utjecaj proizvodnog i geografskog baznog rizika na učinkovitost vremenskih izvedenica i zaključili da pravilan odabir meteorološkog elementa koji će biti u podlozi vremenske izvedenice više doprinosi učinkovitosti vremenskih izvedenica nego inzistiranje da vremenska izvedenica bude pisana na lokalnu meteorološku postaju. Drugim riječima, potvrdili su da proizvodni bazni rizik ima veći utjecaj na učinkovitost vremenskih izvedenica od geografskog baznog rizika, iako je uvriježeno suprotno mišljenje, što potvrđuje velik broj studija koje istražuju geografski bazni rizik i mali broj studija kaje se bave preostalim vrstama baznog rizika.

\subsection{Indeksni bazni rizik}

Poljoprivredna djelatnost dobar je primjer djelatnosti u kojoj veći broj meteoroloških elemenata ima značajan utjecaj na zavisnu varijablu poslovanja. U tom slučaju nije dovoljno utvrditi koji meteorološki element ima jači utjecaj (kako bi 
se eliminirao proizvodni bazni rizik), već je potrebno vremenski indeks kreirati na osnovu dva ili više značajnih meteoroloških elemenata. Tako se, primjerice, u proizvodnji vinove loze kao relevantan meteorološki indikator koristi RibereauGayon i Peynaud (RGP) hidrotermalni indeks koji uzima u obzir utjecaj temperature i kiše (Zara, 2010), a u mljekarstvu tzv. THI (temperature-humidity index) indeks koji mjeri stres kojeg visoke temperature i niska vlažnost zraka izazivaju kod krava muzara i posljedično uzrokuju manju laktaciju (Chen i Roberts, 2004; Chen, Roberts i Thraen, 2006; Deng et al., 2007).

Većina vremenskih izvedenica na tržištu kreirana je na osnovu jednog meteorološkog elementa, uglavnom temperature, jer prikupljanje i analiza većeg broja meteoroloških podataka poskupljuje i komplicira postupanje s vremenskim izvedenicama. U slučaju kada su poslovni subjekti izloženi značajnom utjecaju većeg broja meteoroloških elemenata, a štite se od vremenskog rizika jednostavnom vremenskom izvedenicom kreiranom na osnovu jednog meteorološkog elementa, izlažu se indeksnom baznom riziku (engl. reference-index basis risk) (Chen i Roberts, 2004). Indeksni bazni rizik često je praktično ograničenje prilikom primjene vremenskih izvedenica. Primjerice, Van Lennep et al. (2004), iako ne koriste termin indeksni bazni rizik, ističu problem utjecaja većeg broja meteoroloških elemenata na uzgoj vinove loze, dok se većina vremenskih izvedenica zasniva na osnovu samo jednog meteorološkog elementa - temperature. Međutim, samo su Chen i Roberts (2004) empirijski ispitali utjecaj indeksnog baznog rizika na učinkovitost vremenskih izvedenica kao instrumenata zaštite od vremenskog rizika. Autori su uspoređivali učinkovitost vremenskih izvedenica kreiranih na osnovu THI indeksa (koji je široko prihvaćen kao relevantan meteorološki indikator) s učinkovitošću vremenskih izvedenica kreiranih na osnovu temperature (koja čini podlogu većine vremenskih izvedenica) u zaštiti od vremenskog rizika u proizvodnji kravljeg mlijeka. Rezultati pokazuju da postojanje indeksnog baznog rizika smanjuje učinkovitost vremenskih izvedenica, odnosno da su izvedenice na osnovu temperature manje učinkovite u zaštiti proizvodnje mlijeka od vremenskog rizika u usporedbi s vremenskim izvedenicama na osnovu THI indeksa. Isti autori ispitivali su i utjecaj geografskog baznog rizika na učinkovitost vremenskih izvedenica i zaključili da geografski bazni rizik izaziva veće smanjenje učinkovitosti vremenskih izvedenica od indeksnog baznog rizika.

Želi li se minimizirati indeksni bazni rizik, preporuča se sklopiti vremensku transakciju na OTC tržištu. Međutim, u tom slučaju zainteresirani poslovni subjekti trebaju izvršiti kompromis između indeksnog baznog rizika s jedne strane, i više cijene i niže likvidnosti sklopljenih ugovora s druge strane. 


\subsection{Lokalni bazni rizik}

Lokalni bazni rizik (engl. local basis risk) jest pokazatelj u kojoj je mjeri određena vremenska izvedenica pisana na lokalnu meteorološku stanicu nesavršen instrument zaštite od vremenskog rizika (Woodard i Garcia, 2007). To znači da iako poslovni subjekt sklopi vremensku izvedenicu na konkretnu lokaciju na kojoj je izložen vremenskome riziku (i tako ne bude izložen geografskom baznom riziku), isplata po vremenskoj izvedenici i dalje ne mora biti dovoljna za pokriće nastale financijske štete. Lokalni bazni rizik javlja se zbog nesavršene povezanosti između vremenskih prilika i zavisne varijable poslovanja. Slijedom navedenog može se zaključiti da lokalni bazni rizik ujedno obuhvaća indeksni, proizvodni i temporalni bazni rizik.

\section{Diskusija}

Empirijski je potvrđeno da postojanje baznog rizika umanjuje učinkovitost vremenskih izvedenica u energetici (Golden, Wang i Yang, 2007; Yang, Brockett i Wen, 2009; Yang, Li i Wen, 2011), ratarstvu (Woodarad i Garcia, 2007) i mljekarstvu (Chen i Roberts, 2004; Deng et al., 2007). U tablici 1. sažeto su prikazane studije u kojima je empirijski istraživan utjecaj baznog rizika na učinkovitost vremenskih izvedenica, te međuodnos pojedinih vrsta baznog rizika. 


\section{Tablica 1.}

\section{PRIKAZ STUDIJA O UTJECAJU BAZNOG RIZIKA NA UČINKOVITOST VREMENSKIH IZVEDENICA}

\begin{tabular}{|c|c|c|c|c|}
\hline $\begin{array}{l}\text { Autori } \\
\text { studije }\end{array}$ & $\begin{array}{l}\text { Istraživani } \\
\text { bazni rizik }\end{array}$ & $\begin{array}{l}\text { Zavisna } \\
\text { varijabla }\end{array}$ & Analiza & Rezultat \\
\hline $\begin{array}{l}\text { Yang, Li } \\
\text { i Wen } \\
\text { (2011) }\end{array}$ & $\begin{array}{l}\text { Geografski } \\
\text { bazni rizik }\end{array}$ & $\begin{array}{l}\text { Potrošnja } \\
\text { električne } \\
\text { energije }\end{array}$ & $\begin{array}{l}\text { Usporedba učinkovitosti } \\
\text { standardiziranih (ne-lokalnih) } \\
\text { i nestandardiziranih (lokalnih) } \\
\text { vremenskih izvedenica. }\end{array}$ & $\begin{array}{l}\text { Standardizirane vremenske izvedenice manje } \\
\text { učinkovite od nestandardiziranih, tj. bazni } \\
\text { rizik umanjuje učinkovitost vremenskih } \\
\text { izvedenica. Bazni rizik varira po mjesecima. }\end{array}$ \\
\hline \multirow[t]{2}{*}{$\begin{array}{l}\text { Yang, } \\
\text { Brockett } \\
\text { i Wen } \\
(2009)\end{array}$} & $\begin{array}{l}\text { Geografski } \\
\text { bazni rizik }\end{array}$ & $\begin{array}{l}\text { Potrošnja } \\
\text { električne } \\
\text { energije }\end{array}$ & $\begin{array}{l}\text { Usporedba učinkovitosti } \\
\text { standardiziranih (jedna ne-lokalna } \\
\text { postaja) i nestandardiziranih } \\
\text { (regionalnih) vremenskih izvedenica. }\end{array}$ & $\begin{array}{l}\text { Nestandardizirane (regionalne) vremenske } \\
\text { izvedenice nisu konzistentno učinkovitije, } \\
\text { tj. veći bazni rizik ne podrazumijeva uvijek } \\
\text { manju učinkovitost vremenskih izvedenica. }\end{array}$ \\
\hline & $\begin{array}{l}\text { Temporalni } \\
\text { bazni rizik }\end{array}$ & $\begin{array}{l}\text { Potrošnja } \\
\text { električne } \\
\text { energije }\end{array}$ & $\begin{array}{l}\text { Usporedba učinkovitosti vremenskih } \\
\text { izvedenica u ljetnom i zimskom pod- } \\
\text { periodu. }\end{array}$ & $\begin{array}{l}\text { Učinkovitost vremenskih izvedenica veća } \\
\text { ljeti nego zimi, tj. bazni rizik veći zimi } \\
\text { nego ljeti. Bazni rizik varira po sezonama i } \\
\text { mjesecima. }\end{array}$ \\
\hline \multirow[t]{3}{*}{$\begin{array}{l}\text { Woodarad } \\
\text { i Grcia } \\
(2007)\end{array}$} & $\begin{array}{l}\text { Geografski } \\
\text { bazni rizik }\end{array}$ & $\begin{array}{l}\text { Proizvodnja } \\
\text { kukuruza }\end{array}$ & $\begin{array}{l}\text { Usporedba učinkovitosti } \\
\text { standardiziranih (jedna ne-lokalna } \\
\text { postaja) i nestandardiziranih } \\
\text { (regionalnih) vremenskih izvedenica. }\end{array}$ & $\begin{array}{l}\text { Nestandardizirane (regionalne) vremenske } \\
\text { izvedenice učinkovitije od vremenskih } \\
\text { izvedenica pisanih na jednu ne-lokalnu } \\
\text { postaju, tj. bazni rizik umanjuje učinkovitost } \\
\text { vremenskih izvedenica. }\end{array}$ \\
\hline & $\begin{array}{l}\text { Proizvodni } \\
\text { bazni rizik }\end{array}$ & $\begin{array}{l}\text { Proizvodnja } \\
\text { kukuruza }\end{array}$ & $\begin{array}{l}\text { Usporedba učinkovitosti vremenskih } \\
\text { izvedenica na kišu i temperaturu. }\end{array}$ & $\begin{array}{l}\text { Temperaturne izvedenice učinkovitije. Bazni } \\
\text { rizik umanjuje učinkovitost vremenskih } \\
\text { izvedenica. }\end{array}$ \\
\hline & $\begin{array}{l}\text { Proizvodni } \\
\text { i geografski } \\
\text { bazni rizik }\end{array}$ & $\begin{array}{l}\text { Proizvodnja } \\
\text { kukuruza }\end{array}$ & $\begin{array}{l}\text { Utjecaj proizvodnog i geografskog } \\
\text { rizika na učinkovitost vremenskih } \\
\text { izvedenica. }\end{array}$ & $\begin{array}{l}\text { Proizvodni bazni rizik više umanjuje } \\
\text { učinkovitost vremenskih izvedenica od } \\
\text { geografskog baznog rizika. }\end{array}$ \\
\hline $\begin{array}{l}\text { Golden, } \\
\text { Wang } \\
\text { i Yang } \\
(2007) \\
\end{array}$ & $\begin{array}{l}\text { Geografski } \\
\text { bazni rizik }\end{array}$ & $\begin{array}{l}\text { Potrošnja } \\
\text { električne } \\
\text { energije }\end{array}$ & $\begin{array}{l}\text { Utjecaj vremenskog, baznog i } \\
\text { kreditnog rizika na učinkovitost } \\
\text { baznog hedginga. }\end{array}$ & $\begin{array}{l}\text { Bazni rizik umanjuje učinkovitost baznog } \\
\text { hedginga. }\end{array}$ \\
\hline $\begin{array}{l}\text { Deng et al. } \\
\text { (2007) }\end{array}$ & $\begin{array}{l}\text { Temporalni } \\
\text { bazni rizik }\end{array}$ & $\begin{array}{l}\text { Proizvodnja } \\
\text { kravljeg } \\
\text { mlijeka }\end{array}$ & $\begin{array}{l}\text { Usporedba učinkovitosti vremenskih } \\
\text { izvedenica koje pokrivaju ukupni } \\
\text { period i izdvojene pod-periode. }\end{array}$ & $\begin{array}{l}\text { Vremenske izvedenice za pojedine pod- } \\
\text { periode učinkovitije od jedinstvene } \\
\text { vremenske izvedenice za cijeli period, } \\
\text { tj. bazni rizik umanjuje učinkovitost } \\
\text { vremenskih izvedenica. }\end{array}$ \\
\hline \multirow[t]{2}{*}{$\begin{array}{l}\text { Chen i } \\
\text { Roberts } \\
(2004)\end{array}$} & $\begin{array}{l}\text { Indeksni } \\
\text { bazni rizik }\end{array}$ & $\begin{array}{l}\text { Proizvodnja } \\
\text { kravljeg } \\
\text { mlijeka }\end{array}$ & $\begin{array}{l}\text { Usporedba učinkovitost vremenskih } \\
\text { izvedenica na složeni temperaturni } \\
\text { indeks (THI) i na temperaturu. }\end{array}$ & $\begin{array}{l}\text { Vremenske izvedenice na THI indeks } \\
\text { učinkovitije od vremenskih izvedenica na } \\
\text { temperaturu, tj. indeksni bazni rizik umanjuje } \\
\text { učinkovitost vremenskih izvedenica. }\end{array}$ \\
\hline & $\begin{array}{l}\text { Geografski } \\
\text { i indeksni } \\
\text { bazni rizik }\end{array}$ & $\begin{array}{l}\text { Proizvodnja } \\
\text { kravljeg } \\
\text { mlijeka }\end{array}$ & $\begin{array}{l}\text { Utjecaj indeksnog i geografskog rizika } \\
\text { na učinkovitost vremenskih izvedenica. }\end{array}$ & $\begin{array}{l}\text { Geografski bazni rizik više umanjuje } \\
\text { učinkovitost od indeksnog baznog rizika. }\end{array}$ \\
\hline
\end{tabular}

Izvor: Autorica 
Studije Yanga, Lia i Wena (2011) i Woodarada i Garcie (2007) očekivano potvrđuju da geografski bazni rizik umanjuje učinkovitost vremenskih izvedenica u zaštiti od vremenskog rizika. Za razliku od toga, rezultati studije Yanga, Brocketta i Wena (2009) pokazuju da nestandardizirane regionalne vremenske izvedenice pisane na ponderirane vremenske indekse nisu konzistentno učinkovitije od standardiziranih. Rezultati variraju po mjesecima i gradovima, i potrebno ih je uzeti sa zadrškom, posebice zbog toga što su uspoređivane dvije izvedenice od kojih obje podrazumijevaju određeni geografski bazni rizik, a ne izvedenice pisane na lokalnu i ne-lokanu mjernu postaju što je uobičajena situacija. Nadalje, Golden, Wang i Yang (2007) potvrđuju da geografski bazni rizik umanjuje učinkovitost zaštite od vremenskog rizika i kada je riječ o baznom hedgingu. Što se tiče temporalnog baznog rizika, studije očekivano potvrđuju da smanjuje učinkovitost vremenskih izvedenica u energetici (Yang, Brockett i Wen, 2009) i mljekarstvu (Deng et al., 2007). Rezultati su istovjetni i kada je riječ o proizvodnom baznom riziku (Woodarad i Garcia, 2007) i indeksnom baznom riziku (Chen i Roberts, 2004). S obzirom da je u velikoj većini slučajeva potvrđeno da postojanje baznog rizika umanjuje učinkovitost vremenskih izvedenica u zaštiti od vremenskog rizika, neovisno o vrsti baznog rizika i djelatnosti u kojoj se izvedenica primjenjuje, potvrđuje se inicijalno postavljena hipoteza.

S druge strane, nemoguće je donijeti jedinstveni zaključak o težini pojedinih vrsta baznih rizika u ukupnom baznom riziku s kojim se susreću korisnici vremenskih izvedenica što zbog nedovoljne zastupljenosti istraživanja na tu temu, što zbog jedinstvenosti izloženosti pojedinih djelatnosti vremenskome riziku. Tako je primjerice potvrđeno da u ratarstvu, u proizvodnji kukuruza, proizvodni bazni rizik ima veći (negativni) utjecaj na učinkovitost vremenskih izvedenica od geografskog baznog rizika (Woodarad i Garcia, 2007), dok rezultati studije provedene u stočarstvu u proizvodnji mlijeka pokazuju da geografski bazni rizik ima veći (negativni) utjecaj na učinkovitost od indeksnog baznog rizika (Chen i Roberts, 2004). Svakako su potrebna daljnja istraživanja kako bi se omogućilo jasnije i detaljnije razumijevanje međuodnosa pojedinih vrsta baznih rizika i njihova međuzavisna utjecaja na učinkovitost vremenskih izvedenica.

Ono što je bitno istaknuti jest da u svim studijama, iako je postojanje baznog rizika umanjilo učinkovitost vremenskih izvedenica u zaštiti od vremenskog rizi$\mathrm{ka}$, to smanjenje nije bilo toliko drastično da bi se u potpunosti istisnuo pozitivan učinak primjene vremenskih izvedenica. Bazni rizik svakako je najmanji kada je zavisna varijabla poslovanja visoko korelirana s vremenskim indeksom, kada je vremenski indeks mjeren na optimalnoj lokaciji, te kada se koriste vremenske izvedenice primjerene strukture i veličine. Iz tog razloga, prije samog ulaska na tržište vremenskih izvedenica potrebno je provesti detaljnu analizu osjetljivosti poslovanja na vremenske prilike. Uobičajena metoda za provođenje analize osjet- 
ljivosti jest regresijska analiza odnosno regresiranje zavisnih rezultata poslovanja na relevantne meteorološke elemente. Specifičnosti vremenskog rizika poput visoke lokaliziranosti vremenskih prilika i jedinstvenosti prirode utjecaja vremenskih prilika na poslovanje poduzeća zahtijevaju provođenje analize osjetljivosti poslovanja na vremenske prilike za svaki gospodarski sektor, poslovni subjekt, aktivnost i lokaciju zasebno.

\section{Zaključak}

Bazni rizik na tržištu vremenskih izvedenica definira se kao rizik, odnosno kao opasnost, da isplata po vremenskoj izvedenici neće biti dovoljna za pokriće financijske štete prouzročene vremenskim prilikama, a mjeri se kao razlika između stvarne financijske štete i isplate po vremenskoj izvedenici. Do odstupanja isplate po vremenskoj izvedenici od štete prouzročene vremenskim prilikama dolazi zbog toga što se isplata zasniva na vrijednosti vremenskog indeksa, a ne na stvarno nastaloj financijskoj šteti. Vezivanjem isplate uz vrijednost vremenskog indeksa osigurana je potpuna objektivnost, eliminiran problem moralnog hazarda i minimizirana mogućnost nepovoljne selekcije što slovi kao najveća prednost vremenskih izvedenica spram klasičnog osiguranja, ali se time korisnici ujedno izlažu baznom riziku. Drugim riječima, kreiranjem zaštite od vremenskog rizika u obliku vremenskih izvedenica, korisnici su zamijenili vremenski rizik, ili jedan njegov dio, za bazni rizik.

Bazni rizik proizlazi iz nesavršenosti korelacije isplate po vremenskoj izvedenici i štete prouzročene vremenskih prilikama, a sama nesavršenost korelacije rezultat je većeg broja činitelja. Nesavršenost korelacije između isplate po vremenskoj izvedenici i nastale štete može biti rezultat nesavršenosti korelacije između vremenskog indeksa u podlozi vremenske izvedenice i zavisnih rezultata poslovanja te nepodudaranja vremenskog perioda i lokacije meteorološke stanice na koju glasi vremenska izvedenica sa izloženošću stvarne lokacije koju se želi zaštititi. U skladu s time, moguće je izdvojiti ukupno pet vrsta baznog rizika na tržištu vremenskih izvedenica; geografski, temporalni, proizvodni, indeksni i lokalni bazni rizik.

Postojanje baznog rizika neupitno umanjuje učinkovitost vremenskih izvedenica u zaštiti od vremenskog rizika, što dokazuju rezultati brojnih istraživanja provedenih u različitim djelatnostima, čime se potvrđuje inicijalno postavljena hipoteza. Bitno je istaknuti da se ne mogu sve vrste baznog rizika promatrati jednako jer na neke vrste baznog rizika poslovni subjekti mogu utjecati više, na neke manje, a na neke ne mogu uopće. Štoviše, bazni rizik nikad nije moguće u potpunosti 
otkloniti, tek minimizirati upotrebom precizno kreiranih vremenskih izvedenica. Također, ne postoje konzistentni zaključci o tome koja vrsta baznog rizika ima dominantan utjecaj na smanjenje učinkovitosti vremenskih izvedenica. Najčešće istraživana vrsta baznog rizika, geografski bazni rizik, ujedno je i bazni rizik s kojim se korisnici vremenskih izvedenica najčešće susreću i u većini slučajeva lako je otklonjiv kreiranjem nestandardizirane vremenske izvedenice na lokalnu meteorološku postaju. Za razliku od toga, preostale vrste baznog rizika nemoguće je u potpunosti otkloniti iz praktičnih razloga jer bi kreiranje toliko personalizirane vremenske izvedenice značajno otežalo i poskupilo postupanje s vremenskim izvedenicama. Međutim, istraživanja također pokazuju kako smanjenje učinkovitosti vremenskih izvedenica izazvano baznim rizikom nije toliko drastično da bi rezultiralo potpunom neučinkovitošću vremenskih izvedenica u zaštiti od vremenskog rizika, neovisno o djelatnosti u kojoj se vremenske izvedenice koriste.

\section{Literatura}

1. Alexander, C. (2008) Market Risk Analysis III: Pricing, Hedging and Trading Financial Instruments, West Sussex: John Wiley \& Sons

2. Auer, J. (2003) Weather Derivatives Heading for Sunny Times, Frankfurt Voice, Deutsche Bank Research.

3. Banks, E. (2004) Alternative Risk Transfer - Integrated Risk Management through Insurance, Reinsurance, and the Capital Markets, New Jersey: John Wiley \& Sons

4. Bartram, S.M. (2000) Corporate risk management as a lever for shareholder value creation, Financial markets, institutions and instruments, 9 (5); 279324.

5. Blom, J.E. (2009) Hedging revenues with weather derivatives, Magistarski rad, Norwegian School of Economics

6. Brockett, P. L., Wang, M., Yang, C. (2005) Weather derivatives and weather risk management, Risk Management and Insurance Review, 8 (1); 127-139.

7. Cafiero, C., Angelucci, F., Capitanio, F., Vollaro, M. (2007) Index based compensation for weather risk in the Italian agriculture. A feasibility study based on actual historic data, 101st EAAE Seminar "Management of Climate Risks in Agriculture", Berlin, Njemačka, 5-6. srpanj

8. Chen, G., Roberts, M.C. (2004) Weather Derivatives in the Presence of Index and Geographical Basis Risk: Hedging Dairy Profit Risk, NCR-134 
Conference on Applied Commodity Price Analysis, Forecasting and Market Risk Management, St. Louis, Missouri, 19-20. travanj

9. Chen, G., Roberts, M.C., Thraen, C.S. (2006) Managing Dairy Profit Risk Using Weather Derivatives, Journal of Agricultural and Resource Economics, 31 (3); 653-666.

10. CME (2018) Temperature Based Indexes. Dostupno na: http://www.cmegroup.com/ trading/weather/temperature-based-indexes.html (pristupljeno 20. ožujka 2018.)

11. Considine, G. (2000) Introduction to Weather Derivatives, Aquila Energy. Dostupno na https://agriskmanagementforum.org/sites/agriskmanagementforum.org/files/Documents/weather\%20derivatives\%5B1\%5D.pdf (pristupljeno 22. ožujka 2018.)

12. Dalhaus, T., Musshoff, O., Finger, R. (2018) Phenology Information Contributes to Reduce Temporal Basis Risk in Agricultural Weather Index Insurance, Scientific Reports, 8 (1); 1-10. DOI: 10.1038/s41598-017-18656-5

13. Deng, X., Barnett, B.J., Vedenov, D.V., West, J.W. (2007) Hedging dairy production losses using weather-based index insurance, Agricultural Economics, $36(2) ; 271-280$.

14. Dischel, R.S. (2002) Climate risk and the weather market: Financial risk management with weather hedges, London: Risk Waters Group

15. Ederington, L.H. (1979) The Hedging Performance of the New Futures Markets, The Journal of Finance, 34 (1); 157-170.

16. Ender, M., Zhang, R. (2015) Efficiency of weather derivatives for Chinese agriculture industry, China Agricultural Economic Review, 7 (1); 102-121. DOI: 10.1108/CAER-06-2013-0089

17. Gardner, L. (2003) New Options for Managing Agricultural Weather Risk, CPCU eJournal, 56 (8); 1-23.

18. Golden, L., Wang, M., Yang, C. (2007) Handling Weather Related Risk Through the Financial Markets: Considerations of Credit Risk, Basis Risk, and Hedging, The Journal of Risk and Insurance, 74 (2); 319-346.

19. Jewson, S., Brix, A. (2005) Weather Derivative Valuation: The Meteorological, Statistical, Financial and Mathematical Foundations, Cambridge: Cambridge University Press,

20. Jones, T.L. (2007) Agricultural Applications Of Weather Derivatives, International Business \& Economics Research Journal, 6 (6); 53-60.

21. Lazibat, T., Štulec, I., Baković, T. (2011) Specifičnosti trgovanja vremenskim izvedenicama ovisno o organiziranosti terminskog tržišta, Zbornik Ekonomskog fakulteta u Zagrebu, 9 (1); 1-16. 
22. Lazibat, T., Županić, I., Baković, T. (2009) Vremenske izvedenice kao instrumenti terminskog tržišta, Ekonomska misao i praksa, 18 (1); 59-81.

23. Lazo, J.K., Lawson, M., Larsen, P.H., Waldman, D.M. (2011) U.S. economic sensitivity to weather variability, Bulletin of American Meteorological Society, 92 (6); 709-720. DOI:10.1175/2011BAMS2928.1

24. Leggio, K.B. (2007) Using weather derivatives to hedge precipitation exposure, Managerial Finance, 33 (4); 246-252.

25. Leggio, K.B., Lien, D. (2002) Hedging gas Bills with Weather Derivatives, Journal of Economics and Finance, 26 (1); 88-100. DOI: 10.1007/ BF02744454

26. Lin, J., Boyd, M., Pai, J., Porth, L., Zhang, Q., Wang, K. (2015) Factors affecting farmers' willingness to purchase weather index insurance in the Hainan Province of China, Agricultural Finance Review, 75 (1); 103-113. DOI: 10.1108/AFR-02-2015-0007

27. Liu, X. (2006) Weather Derivatives: A Contemporary Review and Its Application in China, Magistarski rad, University of Nottingham

28. Manfredo, M.R., Richards, T.J. (2009) Hedging with weather derivatives: a role for options in reducing basis risk, Applied Financial Economics, 19 (2); 87-97. DOI: 10.1080/09603100701765166

29. Marković, T., Jovanović, M. (2011) Risk management in plant production with weather derivatives, Contemporary Agriculture, 60 (1-2) 1-6.

30. Moser, J., Helms, B.T. (1990) An Examination of Basis Risk Due to Estimation: Introduction, The Journal of Futures Markets, 10 (5) 457-468.

31. Mseddi, S, Abid, F. (2010) Corporate hedging strategy and firm value, International Research Journal of Finance and Economics, 44 (44); 105128.

32. NN (88/08), Zakon o tržištu kapitala, članak 3., Zagreb: Narodne novine

33. Pres, J. (2009) Measuring Non-Catastrophic Weather Risk for Business, The Geneva Papers, 34 (3); 425-439.

34. Ritter, M., Mußhoff, O., Odening, M. (2014) Minimizing Geographical Basis Risk of Weather Derivatives Using A Multi-Site Rainfall Model, Computational Economics, 44 (1); 67-86.

35. Rohrer, M.B. (2004) The relevance of basis risk in the weather derivatives market. U: Constantino, M., Brebbia, C.A. (ur.) Computational Finance and its Applications, Southampton, UK: WIT Press; 67-76.

36. Schmit, J.T., Roth, K. (1990) Cost Effectiveness of Risk Management Practices, The Journal of Risk and Insurance, 57 (3); 455-470. 
37. Sinha, T., Baqueiro, E. (2005) Rainfall Insurance with Derivatives, Social Science Research Network. Dostupno na SSRN: http://ssrn.com/abstract $=839208$ (pristupljeno 22. ožujka 2018.)

38. Spaulding, A., Kanakasabai, M., Hao, J., Skees, J. (2003) Can weather derivative contracts help mitigating agricultural risk? Microeconomic policy implications for Romania, International Conference on Policy Modeling, Istanbul, srpanj 3-5.

39. Stulz, R.M. (1996) Rethinking Risk Management, Journal of Applied Corporate Finance, 9 (3); 8-25.

40. Štulec, I. (2017) Effectiveness of Weather Derivatives as a Risk Management Tool in Food Retail: The Case of Croatia, International Journal of Financial Studies, 5 (2); 1-15. DOI: 10.3390/ijfs5010002

41. Tang, C.H., Jang, S.C. (2011) Weather risk in ski resorts: Financial hedging and geographical diversification, International Journal of Hospitality Management, 30 (2); 301-311.

42. Torriani, D.S., Calanca, P., Beniston, M., Führer, J. (2008) Hedging with Weather Derivatives to Cope with Climate Variability and Change in Grain Maize Production, Agricultural Finance Review, 68 (1); 67-81.

43. Turvey, C.G. (2005) The pricing of degree-day weather options, Agricultural Finance Review, 65 (1); 59-85. DOI: 10.1108/00214660580001167

44. Url, T., Sinabell, F., Heinschink, K. (2018) Addressing basis risk in agricultural margin insurances: The case of wheat production in Austria, Agricultural Finance Review, 78 (2); 233-245. DOI: 10.1108/AFR-06-2017-0055

45. van Asseldonk, M.A.P.M. (2003) Insurance against weather risk: Use of heating degree-days from non-local stations for weather derivatives, Theoretical and Applied Climatology, 74 (1-); 137-144. DOI: 10.1007/s00704-002-0701-9

46. Van Lennep, D., Oetomo, T., Stevenson, M., de Vries, A. (2004) Weather Derivatives: An Attractive Additional Asset Class, The Journal of Alternative Investments, 77 (2); 65-74.

47. Vedenov, D., Sanchez, L. (2011) Weather Derivatives as Risk Management Tool in Ecuador: A Case Study of Rice Production, Southern Agricultural Economics Association Annual Meeting, Corpus Christi, Texas, 5-8. veljače

48. Vedenov, D.V., Barnett, B.J. (2004) Efficiency of Weather Derivatives as Primary Crop Insurance Instruments, Journal of Agricultural and Resource Economics, 29 (3); 387-403.

49. Wang, M., Wen, M.M., Yang, C.C. (2010) Weather derivatives, price forwards and corporate risk management, The Journal of Risk Finance, 11 (4); 358-376. 
50. Weatherbill (2008) Global Sensitivity: A Comparative Study. Dostupno na: https://www.yumpu.com/en/document/view/36007341/global-weather-sensitivity-a-comparative-study-albertotroccoliorg (pristupljeno 28. ožujka 2018.)

51. Woodard, J.D., Garcia, P. (2007) Basis Risk and Weather Hedging Effectiveness, 101. European Association of Agricultural Economists Seminar „Management of Climate Risks in Agriculture”, Berlin, Njemačka, 5-6. srpanj

52. Yang, C.C., Brockett, P.L., Wen, M.M. (2009) Basis risk and hedging efficiency of weather derivatives, The Journal of Risk Finance, 10 (5); 517-536.

53. Yang, C.C., Li, L.S., Wen, M.M. (2011) Weather Risk Hedging in the European Markets and International Investment Diversification, The Geneva Risk and Insurance Review, 36 (1); 74-94.

54. Zara, C. (2010) Weather derivatives in the wine industry, International Journal of Wine Business Research, 22 (3); 222-237.

THE CONCEPT AND TYPES OF BASIS RISK

IN THE WEATHER DERIVATIVES MARKET

Summary

Weather derivatives, although present for more than 20 years now, still are an underrepresented area in scientific literature, particularly domestic. As hedging instruments against weather risk, they are used to reduce volatility or uncertainty of future cash flows. In addition to many advantages over alternative methods of weather hedge, weather derivatives are characterized by a significant basis risk which has proven to reduce their effectiveness and thus limit their wider application. The basis risk in the weather derivatives market is specific and complex. Since not all weather derivatives users face the same type of basis risk, a detailed understanding of this problem needs to be developed in order to create an adequate weather risk and basis risk management solution. The purpose of the paper is to explain in detail the concept and types of basis risk in the weather derivatives market, how and why it emerges, its impact on the effectiveness of weather derivatives and how to minimize it. The following scientific methods were used: the method of analysis, classification and descriptiveness, the combined method of arrangement and differences, the method of the common changes, the comparative method, and the methods of concretization, synthesis and generalization. The value of the paper is in providing comprehensive review of possible types of basis risk that weather derivatives users face with, as well as discussing possible ways of basis risk management. Scientific contribution of the paper consists in a single conclusion regarding the impact of the basis risk on the weather derivatives effectiveness, regardless of the sector in which weather derivatives are applied, outlined as a result of numerous research papers review.

Key words: weather risk, weather derivatives, basis risk, hedging effectiveness. 